\title{
The Development Of Attention, Relevance, Confidence, And Satisfaction (ARCS) Model Based on Active Learning to Improve Students'learning Motivation
}

\author{
Riska Widya Pratama ${ }^{1}$, Sudiyanto ${ }^{2}$, Riyadi $^{3}$ \\ 1,2,3 Universitas Sebelas Maret; riskapratama68@ gmail.com
}

\begin{abstract}
This research and development aim to: (1) develop a valid and practical model so that it can improve students' motivation in learning mathematics, (2) know the effectiveness of the active learning based ARCS model. This research refers to the stages of research and development from Borg \& Gall which has been modified by Sukmadinata into 3 stages, namely preliminary studies, product development, and product testing. Data analysis techniques used are descriptive qualitative and quantitative. The research finds that (1) active learning based on ARCS model is valid and practical to improve students' learning motivation in mathematics learning based on the assessment given by education experts of $77.94 \%$ (good category), material experts of $87.14 \%$ (excellent category), and practitioners of $96.56 \%$ (excellent category). (2) The result of the effectiveness test shows that the developed product is effective in increasing students' learning motivation in mathematics learning based on experimental results which shows $\mathrm{p}<0.05$ on learning motivation which means there are significant differences in students who were taught using the ARCS model based on active learning.
\end{abstract}

Keywords: Active Learning, ARCS Model, Learning Motivation, Mathematics

\section{INTRODUCTION}

Mathematics is one of the subjects that are not always easy for students since the teacher should be able to nurture the students' motivation in order to be more interested in mathematics. This is because motivation holds an important role in learning since it is the energy that moves and directs one's activities. Motivation is an internal process that activates, guides, and maintains behavior over time (Slavin, 2006). Motivation is very important in learning because motivation can encourage students to perceive information in learning. Motivation can be cultivated by making mathematics learning activities fun, relaxed, and adapted to the characteristics and needs of students.

Based on the results of the interviews with the teacher and student as well as the observations of the students' activities in Karanganyar Elementary School 02, it is known that motivation for mathematics subjects was still low. This is indicated by the lack of learning attention in the classroom. Students were more engrossed in their own activities, such as talking to their peers or just playing with their writing instruments. The students' curiosity about the material delivered was still lacking. They often gave up when getting a considered difficult task and they tended to not want to try to complete the task. The low learning motivation of students towards mathematics subjects also occurs in Karangtengah State Elementary School 02. Through interviews, it was known that the students tended to dislike mathematics for various reasons. Some of the reasons are that they considered mathematics to be difficult, boring, and dominated by complicated calculation. Similar results were also obtained when the researchers conducted interviews in Jatingarang Public Elementary School 03. The grade IV teachers said 
that mathematics subjects were always a scourge that students feared from time to time. This happened because the students' mindset had been set to think that mathematics is difficult to learn, so motivation to participate in learning activities is also low.

By seeing the results of interviews, observations, and questionnaires described above, one of the causes of students' low learning motivation can be found. The teacher was not developing an interesting and suitable learning model to cover the needs of students. The learning model developed should be student-centered, able to construct knowledge, and can empower students' learning motivation. One model that is suitable according to the researchers is the ARCS model which is a form of a problem-solving approach to design aspects of motivation and learning environment in encouraging and maintaining student motivation to learn.(Keller, 2010) The ARCS model is developed by implementing active learning strategies where the students are invited to learn actively. When students learn actively, it means that they dominate the learning activities. The students could actively think, both to find the main ideas of learning material and solve problems even apply what has been learned in real life.

Based on previous research, various studies used the ARCS model in learning and active learning (Alfiyana, Sukaesih, \& Setiati, 2018; Fitrianingrum, 2015; Piriyasurawong, 2019; Silberman, 2013; Tugun, 2018) as well as research with the aim of increasing students' learning motivation (Amin, 2017; Andrianti, Irawati, \& Sudin, 2016; Anita, 2015; B. Sjukur, 2012; Ghofuri, Sanusi, \& Krisdiana, 2014; Maduretno, Sarwanto, \& Sunarno, 2016; Mayliana \& Sofyan, 2013; Syaifulloh, 2016; Syarif, 2012). However, there is no research that focuses on the ARCS model in active learning to improve students' learning motivation. The renewal of this study lies in the development of ARCS models based onactive learning to improve students' learning motivation. This study combines the syntax of ARCS with the syntax of active learning to produce a new syntax. This is in line with previous research conducted by Winaya, Lasmawan, \& Dantes (2013) about the effect of the ARCS model on students' learning motivation. The research conducted lies in the use of the strategies of active learning. The purpose of this study is (1) to develop a valid and practical model so that it can improve students' learning motivation in mathematics; (2) knowing the effectiveness of the ARCS model based on active learning.

\section{THE RESEARCH METHODS}

This research is a research and development $(\mathrm{R} \& \mathrm{D})$ that uses the development stages proposed by Borg \& Gall which has been modified by Sukmadinata into 3 stages, namely preliminary studies, product development, and product testing (Sukmadinata, 2012). The research subjects are 9 public elementary schools in Weru District, Sukoharjo Regency obtained through multistage random sampling. Data collection techniques used were observation, interviews, document analysis, and questionnaires. Data analysis techniques used were descriptive qualitative and quantitative. The qualitative descriptive technique was used to analyze data at the preliminary stage while the quantitative descriptive technique was used in the product development and testing stages. Meanwhile, the tests of the feasibility of the product were carried out through two stages of testing, namely limited trial and extensive trial. 
Furthermore, to determine the effectiveness of the product, product testing was developed through a quasi-experimental method after which the data analysis or hypothesis testing was carried out using the t-test (independent sample t-test). The assessment results from experts were analyzed quantitatively and qualitatively. The quantitative results in the form of scores were then converted and given qualification criteria qualitatively. The eligibility criteria according to Riduwan is presented in Table 1.

Table 1. Criteria of the Product

\begin{tabular}{cc}
\hline Interval & Category \\
\hline $81 \%<$ score $\leq 100 \%$ & Excellent \\
$61 \%<$ score $\leq 80 \%$ & Good \\
$41 \%<$ score $\leq 60 \%$ & Moderate \\
$21 \%<$ score $\leq 40 \%$ & Bad \\
$0 \%<$ score $\leq 20 \%$ & Poor \\
\hline
\end{tabular}

\section{THE RESULTS OF THE RESEARCH AND THE DISCUSSION}

Research and development of ARCS model based on active learning are based on the results of the needs analysis that was carried out in three public elementary schools in Weru District, namely Karanganyar 02 Public Elementary School, Karangtengah 01 Public Elementary School, and Jatingarang Public Elementary School 03. Through this needs analysis, it is known that the application of innovative learning models is very rare. Learning is stillteacher-centered so students tend to be passive because they only receive information from the learning delivered by the teacher without being involved directly in the learning process. This situation makes students feel bored, less focused, and less interested in participating in teaching and learning activities. This is in contrast with the demands of the 2013 curriculum, which should be student-centered. Active students independently find learning information while teachers act as facilitators. This is in line with the opinion of Silberman who states that I forgot what I heard,I remembered what I saw, and I understood what I did.(Silberman, 2013) Therefore, in order for the students to understand the subject matter delivered by the teacher, the learning must involve students actively.

Starting from the results of the needs analysis, the developed learning model should be student-centered, able to construct knowledge and can empower students' learning motivation. One model that is suitable is the ARCS model which is a form of a problem-solving approach to design aspects of motivation and learning environment in encouraging and maintaining students' motivation to learn. (Keller, 2010) This ARCS learning model prioritizes students' attention, adjusts learning the material to students' learning experiences, creates selfconfidence, and raises satisfaction. The ARCS model is developed by implementing active learning strategies. Through this strategy, the students are invited to learn actively. When students learn actively, they dominate learning activities. Thus, students actively think, both to find the main ideas of learning material, solve problems, and even apply what has been learned in real life. The application of the active learning strategies is also supported by the opinion of Joyo Atmojo, who argues that efforts to foster motivation to learn must be united with the 
learning process based on learners' activeness (Joyoatmojo, 2011). The product of this research is a learning syntax by combining the ARCS model with the active learning strategy contained in the lesson plan (RPP). The new syntax can be seen in Figure 1 below:

\begin{tabular}{|c|c|c|c|}
\hline ARCS Syntax & $\begin{array}{l}\text { ARCS Syntax-Based on } \\
\text { Active Learning }\end{array}$ & \multirow{3}{*}{ 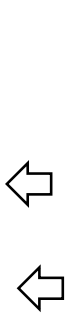 } & $\begin{array}{l}\text { Active Learning } \\
\text { Syntax }\end{array}$ \\
\hline $\begin{array}{c}\text { Generating students' } \\
\text { attention }\end{array}$ & $\begin{array}{c}\text { Generating students' } \\
\text { attention by giving } \\
\text { experiences }\end{array}$ & & Giving experience \\
\hline \multirow{2}{*}{$\begin{array}{l}\text { Creating relevance to } \\
\text { the content of } \\
\text { learning }\end{array}$} & Interacting in learning & & Interacting in \\
\hline & $\begin{array}{l}\text { Creating relevance to } \\
\text { learning content }\end{array}$ & \multirow{3}{*}{ 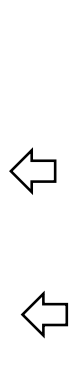 } & \\
\hline $\begin{array}{l}\text { Maintaining student } \\
\text { attention }\end{array}$ & $\begin{array}{l}\text { Maintainingstudents' } \\
\text { attention through } \\
\text { communication }\end{array}$ & & $\begin{array}{l}\text { Communicating or } \\
\text { delivering ideas }\end{array}$ \\
\hline $\begin{array}{l}\text { Growing self- } \\
\text { confidence }\end{array}$ & $\begin{array}{l}\text { Growing self-confidence } \\
\text { through reflection }\end{array}$ & & $\begin{array}{l}\text { Reflecting or } \\
\text { reinforcement of } \\
\text { ideas }\end{array}$ \\
\hline $\begin{array}{l}\text { Creating satisfaction } \\
\text { in learning }\end{array}$ & $\begin{array}{l}\text { Creating satisfaction in } \\
\text { learning }\end{array}$ & & \\
\hline
\end{tabular}

Figure 1. The Integration of ARCS Syntax and Active Learning

This product is equipped with six components of learning development model, namely: 1) theoretical foundation; 2) learning syntax; 3) social systems; 4) the principle of reaction; 5) support systems; and 6) instructional impacts and accompaniment impacts (Joyce, 2008).

Based on the data of the research, the discussion of the research is as follows:

\section{Validity and Practicality ofthe ARCS Modelbased on Active Learning}

The development process followed the procedures proposed by Borg \& Gall which have been modified by Sukmadinata (Sukmadinata, 2012), so that it only consisted of three stages, namely a) preliminary study; b) product development stage; and c) the testing stage. Data from preliminary studies were used as the basis for developing initial products in the form of drafts. Furthermore, the draft was validated by several experts including education experts, material experts, and practitioners, as well as psychologists and learning evaluation. The results of the assessment from experts were then analyzed quantitatively and qualitatively. The quantitative results in the form of scores were then converted and given the eligibility criteria qualitatively.

Based on expert validation, the assessment scores from education expert was $77.94 \%$ with good category, the material expert was $87.14 \%$ with the excellent category, the practitioner was $96.56 \%$, and psychologists and learning evaluations of $93.54 \%$ with the excellent category. In addition to giving assessmentscore, experts also provided advice, criticism, and input that can be used as a reference and basis for researchers in making improvements and refinement of products developed. Furthermore, to determine the feasibility of the product, limited trial and extensive trial were carried out. A limited trial was conducted on 21 students of Karanganyar Elementary School02. In this limited trial, the teacher carried out teaching and learning activities by applying the ARCS model based on active learning.Afterthat, the researchers gave 
a questionnaire related to the practicality of the model to the teacher and questionnaire responses to students. The questionnaire for the practicality of the model shows that the score of the lesson plan aspects was $84 \%$ with excellent category, material aspects was $80 \%$ with good category, student worksheet aspectwas $76 \%$ with good category, and assessment aspect was $88 \%$ with the excellent category. So, the average practicality questionnaire of the model was $82 \%$ with anexcellent category.

The responsesof student questionnaire show the results of the learning aspects of $90.47 \%$ with an excellent category, the material aspects of $86.98 \%$ with an excellent category, and the student worksheet aspect of $88.57 \%$ with an excellent category. Thus, the average response of the student questionnaire was $88.67 \%$ with an excellent category. The results of the limited trial show that the ARCS model based on active learning developed by the researcher received positive responses from teachers and fourth-grade students of Karanganyar Elementary School.

In addition, to determine the feasibility of ARCS modelbased on active learning,the researchers also conducted an extensive trial on 44 students in two different schools, namely 24 students of Karangtengah State Elementary School 02 and 20 students of Jatingarang State Elementary School 03. The implementation of the extensive trial was similar to the implementation of limited trial by applying ARCS models based on active learning in mathematics learning then the researcher gave the practicality questionnaire to the teacher and the questionnaire to the students. The difference is, in the extensive trial, the researchers also provided learning motivation questionnaires to students. The questionnaire of practicality shows the result of the lesson plan aspects of $88 \%$ with an excellent category, material aspects of $94 \%$ with an excellent category, student worksheet aspect of $84 \%$ with an excellent category, and assessment aspect of $90 \%$ with an excellent category. In conclusion, the average practicality questionnaire is $89 \%$ with an excellent category. The questionnaire of student response shows the results of the learning aspect of $93 \%$ with an excellent category, material aspectof $93.47 \%$ with an excellent category, and student worksheet aspect of $92.05 \%$ with an excellent category. Thus, the average student response questionnaire was $93 \%$ with an excellent category. The average result of student learning motivation questionnaire at the pretest and posttest were 40.85 with the low category and 62.8 in the good category. The results of this extensive trial also show that the ARCS model based on active learning developed by the researchers obtained positive responses from teachers and fourth-grade students at Karangtengah State Elementary School 02 and Jatingarang State Elementary School 03.

Based on the description above, the application ofthe ARCS model based on active learning in mathematics could make students interested, enthusiastic, and active in participating in teaching and learning activities. The learning atmosphere is fun and the material presented is easier to understand. Therefore, theARCS model based on active learning developedis declared valid and practical so that it can be used in mathematics learning.

\section{The Effectiveness of the ARCS Model based on Active Learning in Improving} Student Learning Motivation

The effectiveness of the ARCS model based on active learning in improving students' learning motivation can be proven through the effectiveness test using the experimental method. 
The effectiveness test in this study was conducted in six elementary schools in Weru District which were divided into two randomly selected groups, namely the experimental group and the control group. Each group consisted of 3 elementary schools with different levels, namely high, medium, and low. The experimental group carried out teaching and learning activities by applying the ARCS model based onactive learning while the control group carried out teaching and learning activities by not applying the ARCS model based on active learning. To find out the increase in students' learning motivation can be seen through the results of thepretest and posttestanalysis.

The effectiveness test results showed the average pretest score in the experimental group which was 46.76 while in the control group it was 48.6. Furthermore, the average post-test score in the experimental group was 71.63 while in the control group was 55.97. These results indicated that the average experimental group was higher than the control group. To determine whether or not there was an increase in students' learning motivation before and after applying the ARCS model based on active learning, the hypothesis testing was done using the independent sample t-test. Through this test, it was obtained the significance value between the experimental group and the control group at the pretest which was 0.522 , which means greater than 0.05 . Thus it can be concluded that $\mathrm{H}_{0}$ is accepted or the experimental group and the control group have the same initial ability. In other words, there is no significant difference between the learning motivation of the experimental group students and the control group at the pretest. While the significance value of the posttest is 0,000 , which means less than 0.05 , thus, $\mathrm{H}_{0}$ is rejected and $H_{1}$ is accepted.In other words, there is a significant difference in the results between the experimental group and the control group. These results also showed an increase in the motivation of learning in the experimental group that was better than the control group. Starting from the exposure to the results of the pretest and posttest that have been stated,there was an increase in the average student learning motivation in the experimental group by 24.87. The increase in average students' motivation in the control group was 7.37. Thus it can be concluded that the increase in learning outcomes in the experimental group was 17.5 higher than in the control group.

Based on the research data described above, the application of the ARCS modelbased on active learning toward mathematics learning has an effect on increasing students' learning motivation. Its application makes the atmosphere of teaching and learning activities more active, enjoyable, enthusiastic, and interesting towards learning. This means that student motivation in learning also increases where motivation in learning will also affect the success of the teaching and learning process. As stated by Aunurrahman, there are several learning principles that can be developed to achieve success in learning (Aunurrahman, 2013), including a) the principle of attention and motivation; b) the principle of activity; c) the principle of direct involvement; d) principle of learning; e) the principle of feedback and reinforcement; f) the principle of individual differences. Therefore, the application of the ARCS model based on active learning toward mathematics learning can be developed to the characteristics.

The results of this study are in line with some experts' opinions and some previous researchers. The application of the active learning strategy is supported by the opinion of 
Joyoatmojo who argues that efforts to foster motivation to learn must be united with the learning process based on learners' activeness. (Joyoatmojo, 2011) The development of the ARCS model based on active learning also starts from previous research conducted by Fitrianingrum.The results of this study indicate that the development of ARCS-based digital teaching materials with theblended-learning method in the first level of Jarimatika learning is effective. Based on field data on a large-scale field trial, students who succeeded in achieving learning completeness (score> 60) were 12 students (80\%) (Fitrianingrum, 2015).

\section{CONCLUSION AND SUGGESTION}

Based on the results of the research, it can be concluded that (1) The ARCS model based on active learning is valid and practical to improve students' learning motivation in mathematics. This is based on the scores obtained during the experts' assessment. The score from the education expert is $77.94 \%$ with a good category. The score from thematerial expert is $87.14 \%$ with the excellent category and the score from the practitioners is $96.56 \%$ with the excellent category; and (2) the result of the effectiveness test shows that the developed product is effective in increasing students' learning motivation in mathematics learning based on experimental results which shows $\mathrm{p}<0.05$ on learning motivation which means that there is a significant difference on the students who were taught using the ARCS model based on active learning. Therefore, this research is expected to be a solution for teachers and educational practitioners to be able to increase learning motivation, especially in mathematics.

Suggestions that can be given to further the research are that the researchers who want to examine the same problems should be more careful and seek more studies or theories related to learning that apply ARCS model based on active learning since the theory of ARCS model based onactive learning has not developed much. Deeper theoretical studies are used to correct deficiencies in its application as an alternative solution in increasing the effectiveness and quality of the expected impact.

\section{REFERENCES}

Alfiyana, R., Sukaesih, S., \& Setiati, N. (2018). Pengaruh Model ARCS dengan Metode Stick Terhadap motivasi dan Hasil Belajar Siswa Materi Sistem Pencernaan. Unnes Journal of Biology Education, 7(2), 226-236.

Amin, A. K. (2017). Kajian Konseptual Model Pembelajaran Blended Learning berbasis Web untuk Meningkatkan Hasil Belajar dan Motivasi Belajar. Jurnal Pendidikan Edutama, $4(2), 51-64$.

Andrianti, R. Y., Irawati, R., \& Sudin, A. (2016). Pengaruh Pendekatan SAVI (Somatic, Auditory, Visual, Intellectual) dalam Meningkatkan Kemampuan Komunikasi Matematis dan Motivasi Belajar Siswa Sekolah Dasar pada Materi Pengolahan Data. Jurnal Pena Ilmiah, 1(1), 471-480.

Anita, I. W. (2015). Pengaruh Motivasi Belajar Ditinjau Dari Jenis Kelamin Terhadap Kemampuan Berpikir Kritis Matematis Mahasiswa. Jurnal Ilmiah UPT P2M STKIP Siliwangi, 2(2), 246-251. 
Aunurrahman. (2013). Belajar dan Pembelajaran. Bandung: Alfabeta.

B. Sjukur, S. (2012). Pengaruh Blended Learning Terhadap Motivasi Belajar Dan Hasil Belajar Tingkat SMK. Jurnal Pendidikan Vokasi, 2(3), 368-378.

Fitrianingrum, A. (2015). Pengembangan Bahan Ajar Digital Berbasis ARCS (AttentionRelevance-Confidence-Satsfaction) untuk Meningkatkan Keefektifan Pembelajaran Jarimatika dengan Metode Blended Learning di Unit Jarimatika Center Salatiga. Universitas Sebelas Maret.

Ghofuri, A. M., Sanusi, \& Krisdiana, I. (2014). Efektivitas Pembelajaran Berbasis Multimedia Menggunakan Power Point Dengan Pendekatan Pembelajaran Berbasis Masalah (Problem Based Learning) Ditinjau Dari Motivasi Belajar Siswa. JIPM : Jurnal Ilmiah Pendidikan Matematika, 3(1), 1-7.

Joyoatmojo, S. (2011). Pembelajaran Efektif: Pembelajaran yang Membelajarkan. Surakarta: UNS Press.

Keller, J. (2010). Motivational Design for Learning and Perfomance: The ARCS Model Approach. New York: Springer.

Maduretno, T. W., Sarwanto, \& Sunarno, W. (2016). Pembelajaran IPA Dengan Pendekatan Saintifik Menggunakan Model Learning Cycle dan Discovery Learning Ditinjau Dari Aktivitas Dan Motivasi Belajar Siswa Terhadap Prestasi Belajar. JPFK, 2(1), 1-11.

Mayliana, E., \& Sofyan, H. (2013). Penerapan Accelerated Learning Dengan Pendekatan SAVI Untuk Meningkatkan Motivasi dan Hasil Belajar Kompetensi Menggambar Busana. Jurnal Pendidikan Vokasi, 3(1), 14-28.

Piriyasurawong, P. (2019). Active Learning Using ARCS Motivation on Social Cloud Model to Enhance Communicatio Skills in Foreign Language. TEM Journal, 8(1), 290-297.

Silberman, M. L. (2013). Active Learning: 101 Cara Belajar Siswa Aktif. Terj: Raisul Muttaqien. Bandung: Nuansa Cendekia.

Slavin, R. E. (2006). Educational Phsycology: Theory and Practice. Boston: Pearson Education, Inc.

Sukmadinata, N. S. (2012). Metode Penelitian Pendidikan. Bandung: PT Remaja Rosdakarya.

Syaifulloh, A. (2016). Pengaruh Strategi Problem-Based Learning (PBL) terhadap Motivasi dan Hasil Belajar Peserta Didik pada Mata Pelajaran Fiqih di MA Khozinatul 'Ulum Blora Jawa Tengah. Wahana Akademika, 3(2), 121-136.

Syarif, I. (2012). Pengaruh Model Blended Learning Terhadap Motivasi Dan Prestasi Belajar Siswa SMK. Jurnal Pendidikan Vokasii, 2(2), 234-249.

Tugun, V. (2018). Impacts and Opinions on the Technology Self-Sufficiency of the Students who are Coding Education in the Flipped Classroom Adapted to the ARCS Motivation Model. TEM Journal, 7(2), 366-371. 